\title{
Influence of roller - burnishing on surface rough- ness parameters and roundness
}

\author{
Augustín Görög ${ }^{1 *}$, Ingrid Görögová ${ }^{1}$, Dana Stančeková ${ }^{2}$, Miroslav Janota ${ }^{2}$ \\ ${ }^{1}$ Slovak University of Technology in Bratislava, Institute of Production Technologies, Faculty of \\ Materials Science and Technology in Trnava,, Bottova 25, 91724 Trnava, Slovak Republic \\ ${ }^{2}$ University of Žilina, Faculty of Mechanical Engineering, Univerzitna 1, 010 26, Žilina, SK,
}

\begin{abstract}
In order to increase productivity, machining times and market competitiveness of machining production systems, it is important to continuously develop existing technological solutions. The paper deals with surface roughness and roundness after roller burnishing outer rotary surface. Roller burnishing was applied on turned surfaces with different surface roughness. Each outer rotary surface was roller burnished twice with the same conditions (pressing force, peripheral speed of machine part, feed of tool). The parameters of the surface roughness $\mathrm{Ra}, \mathrm{Rq}$ and $\mathrm{Rt}$ were measured after each single roller burnishing. The results show that the surface roughness is decreasing after the first roller burnishing cycle (additional roller burnishing had only negligible influence on surface roughness) and the original surface roughness has a significant influence on change of surface roughness after roller burnishing.
\end{abstract}

Keywords: surface roughness, roundness, roller burnishing, measuring

\section{Introduction}

Surface geometry machined with traditional processes consists of scallops causing additional finishing operation. Surface roughness bellow $0.1 \mathrm{~mm}$ [1] is required for minimizing friction losses and high fatigue strength. To increase production efficiency and these requirements, it is necessary to look either for new tool designs gathering better machining outputs or either for more cheaply actions toward optimization of the machining parameters [2].

Most of the investigations towards improvement of fine machining processes are concerned with the process outputs: surface roughness and surface hardness. It was pointed out by many investigators that an improvement in wear resistance can be very easy achieved by burnishing, but very few actual studies analysed environmental implications and versatility. [3] Roller burnishing (Fig. 1, [4]) is a low-cost surface treatment method of cold working to induce compressive residual stresses in the top surface layer of the burnished material. Stoić at all [3] defined roller burnishing as a fine machining process that is used to improve certain physical and mechanical properties, such as surface roughness, corrosion resistance, friction coefficient, wear, and fatigue resistance. This process is used when the goal is to achieve a high quality surface finish strengthened by the strain hardening

\footnotetext{
* Corresponding author: augustin.gorog@stuba.sk

Reviewers: Sylvia Kuśmierczak, Vladimir Vrba
} 
phenomenon $[5,6]$. In the RB process a cylindrical roller is pressed across the part being processed. The plastic deformation created by the roller is a displacement of the material that flows from peaks into valleys under pressure, and results in a surface finish with a strainhardened surface $[7,8]$.

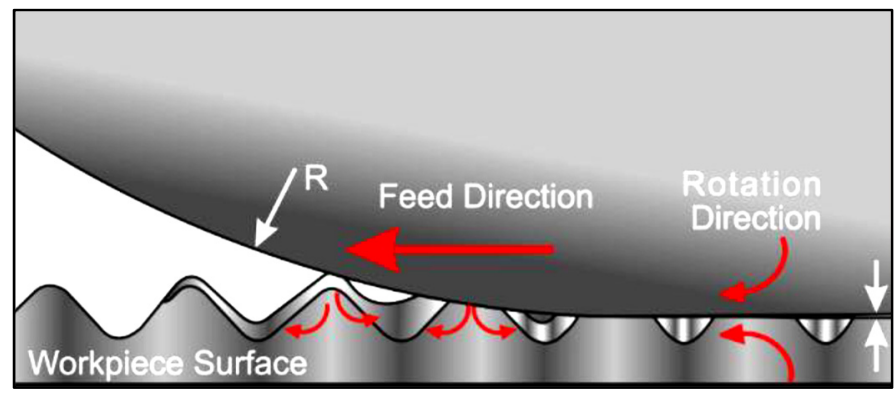

Fig. 1. Scheme of roller burnishing [4]

When roller burnishing is conducted on a lathe, the workpiece is spinning and the burnishing tool is moved across the surface at a constant rate. Many of processes for the manufacturing of high-quality surfaces can be replaced by roller burnishing (e.g. galling, grinding, honing, polishing) [9, 10]. Roller burnishing is commonly applied to cylindrical workpieces on both external and internal surfaces, and its tools are similar to roller bearings [11].

In last few decades roller and ball burnishing have been studied by a number of researchers on various materials. El-Axir [12] found that the burnishing feed and burnishing force feed have the most significant effect on both micro hardness and surface roughness. Luo et al. [13] studied the effect of the burnishing parameters on the burnishing force and material micro hardness via theoretical analysis. The results showed that burnishing depth and feed were the most significant factors. Franzen et al. [14-16] found that the rolling process parameters had a great influence on the tribological properties of burnished surfaces. The optimum hardness and roughness were obtained for a specific regime whose decisive parameters are the applied force and the number of passes of the burnishing tool. El-Tayeb et al. [17-20] investigated the influence of the contact conditions between the roller and workpiece on the quality of the burnished surface as well as tribological behaviour in roller burnishing.

The aim of the article is to experimentally determine the change of surface roughness. Comparison of the original surface roughness of the turned surface with the surface roughness after roller burnishing, respectively after two roller burnishing. On selected surfaces will be monitored change of the roundness, respectively roundness profile.

\section{Experimental methods}

\subsection{Roller burnishing tool}

Burnishing tool (Fig. 2), which was used during experimental work, is duo-trolley toll with dynamometer. The basic dimensions of the tool:

- $\quad$ diameter of the forming rollers $\mathrm{D}=40 \mathrm{~mm}$,

- clamping holder section $\mathrm{s}=35 \times 30 \mathrm{~mm}$,

- clamping holder length $1=160 \mathrm{~mm}$,

- $\quad$ total tool length $\mathrm{L}=320 \mathrm{~mm}$,

- maximum tool height $\mathrm{v}=81 \mathrm{~mm}$,

- $\quad$ maximum tool width $\mathrm{h}=35.5 \mathrm{~mm}$. 
At press tool on cylindrical surface, indicating gauge evince particular deviation. This deviation depends on force parameter, which pressing the burnishing tool.

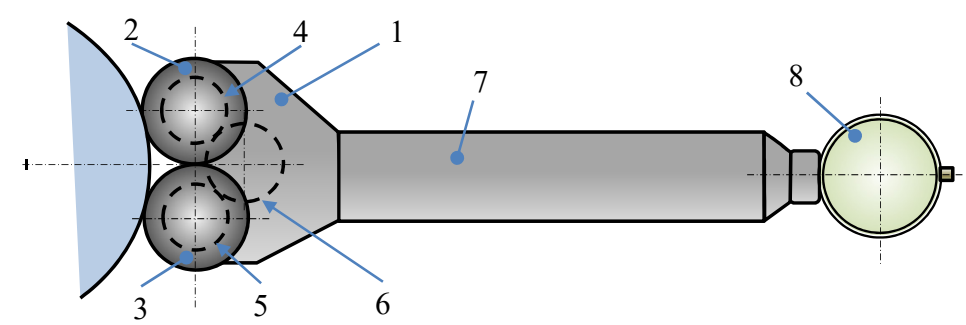

Fig. 2. Burnishing tool: 1 - supporting body of roller head, 2, 3 - rollers, 4, 5, 6 - gear wheel, 7 holder, 8 - dial indicator

Before using roller burnishing tool is necessary to determine functional dependence of deviation reviewed on indicating gauge on pressing power. This reliance was determined by roller burnishing tool pressing using known pressing force to the cylinder with equivalent diameter and material. Pressing force was in range of $0-5000 \mathrm{~N}$. This process use to be called as a device calibration. Obtained relationship of pressing power and deviation is shown in fig. 3 .

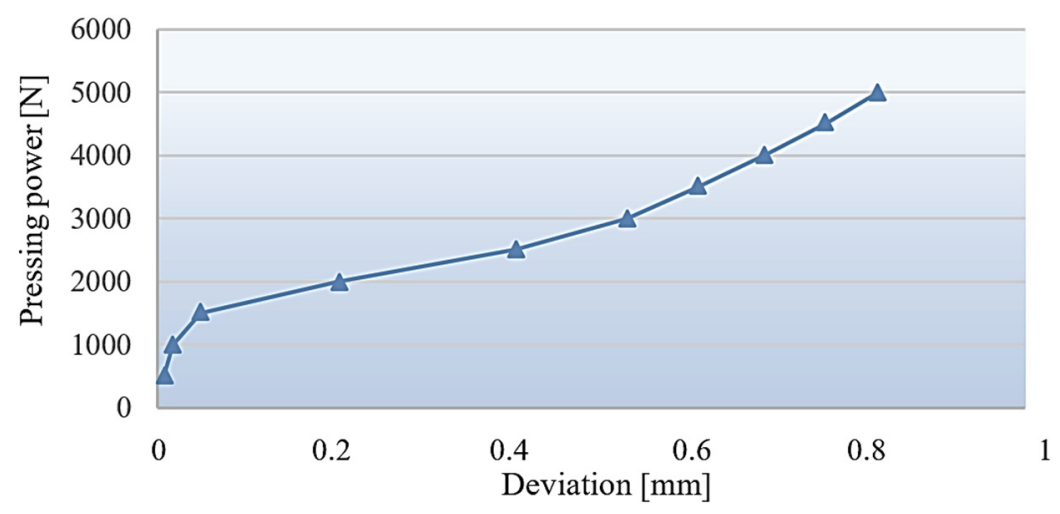

Fig. 3. Obtained relationship of pressing power and deviation

Pressing force was adjusted so, that roller burnishing was pressed step by step into roller burnishing surface and the deviation was reviewed on indication gauge.

\subsection{Workpiece material and experiment conditions}

In the present work, the S $335 \mathrm{~J} 2 \mathrm{G} 3$ steel (diameter $41 \mathrm{~mm}$ ) was used as workpiece material and the chemical composition of material is given in Table 1. The workpiece was selected for present work because this material is mostly used in engineering industries for shafts, spindles, studs, etc. 
Table 1. Chemical composition (in weight \%)

\begin{tabular}{ccccccc}
\hline $\begin{array}{c}\text { Carbon } \\
(\mathbf{C})\end{array}$ & $\begin{array}{c}\text { Manganese } \\
(\mathbf{M n})\end{array}$ & $\begin{array}{c}\text { Silicon } \\
\mathbf{( S i )}\end{array}$ & $\begin{array}{c}\text { Phosphorus } \\
\mathbf{( P )}\end{array}$ & $\begin{array}{c}\text { Sulphur } \\
(\mathbf{S})\end{array}$ & $\begin{array}{c}\text { Nitrogenium } \\
\mathbf{( N )}\end{array}$ & $\begin{array}{c}\text { Aluminium } \\
(\mathbf{A l})\end{array}$ \\
\hline Max. & Max. & Max. & Max. & Max. & & Max. \\
0.200 & 1.600 & 0.550 & 0.050 & 0.045 & - & 0.015 \\
\hline
\end{tabular}

There were turned nine surfaces on the workpiece (Fig. 4) with different surface roughness in random order. The average value of arithmetical mean deviation of the profile Ra was from $1.67 \mu \mathrm{m}$ to $5.34 \mu \mathrm{m}$.

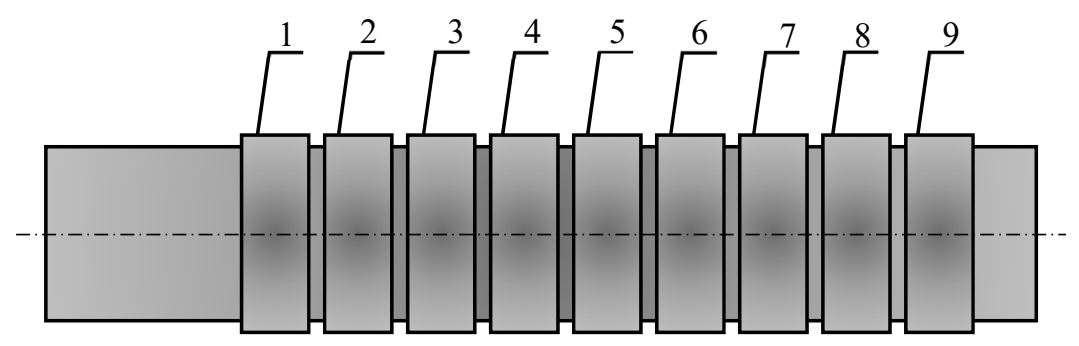

Fig. 4 Shaft used for experiments

All nine surfaces were roller burnished twice under the same conditions:

- Machine: lathe SUI 40,

- Peripheral speed: $72.13 \mathrm{~m} / \mathrm{min}$,

- Pressure force: $3000 \mathrm{~N}$,

- Feed: $0.3 \mathrm{~mm}$ (feed rate $168 \mathrm{~mm} / \mathrm{min}$ ),

- Cooling: oil.

The experimental conditions used in this work were chosen in accordance with the manufacturer's recommendations of the roller burnishing tool.

\section{Attained results}

Surface roughness was measured after each roller burnishing (every surface on the three various places) with device type Surtronic 3+ (Rank Taylor Hobson Ltd., UK). The referent profile length $l_{\mathrm{r}}=0.8 \mathrm{~mm}$, observed length $1_{\mathrm{n}}=4 \mathrm{~mm}$. Three parameters were measured, as declaring the STN EN ISO 4287 standard:

- Arithmetical mean deviation of the profile Ra,

- Root mean square deviation of the profile Rq,

- Total height of profile Rt.

For better view, the smallest and the highest measured data of surface roughness are listed below in tab. 2 .

Table 2. Measured values of surface roughness

\begin{tabular}{ccc}
\hline After turning: & After the first roller burnishing: & After the second roll burnishing: \\
\hline $\mathbf{R a}=\mathbf{1 . 2 5 - 5 . 6 7} \mu \mathrm{m}$ & $>\mathbf{R a}=\mathbf{0 . 6 5 - 0 . 9 9} \mu \mathrm{m}$ & $>\mathbf{R a}=\mathbf{0 . 7 0 - 1 . 3 2} \mu \mathrm{m}$ \\
$>\mathbf{R q}=\mathbf{1 . 5 8 - 6 . 5 1} \mu \mathrm{m}$ & $>\mathbf{R q}=\mathbf{0 . 8 1 - 1 . 2 8} \mu \mathrm{m}$ & $>\mathbf{R q}=\mathbf{0 . 8 8 - 1 . 6 9} \mu \mathrm{m}$ \\
$>\mathbf{R}=\mathbf{9 . 4 - 3 6 . 4} \mu \mathrm{m}$ & $>\mathbf{R}=\mathbf{5 . 6 - 1 0 . 1} \mu \mathrm{m}$ & $>\mathbf{R t}=\mathbf{4 . 9 - 1 2 . 0} \mu \mathrm{m}$
\end{tabular}


The change of surface roughness (parameters Ra, Rq, Rt) is shown in fig. 5, 6 and 7.

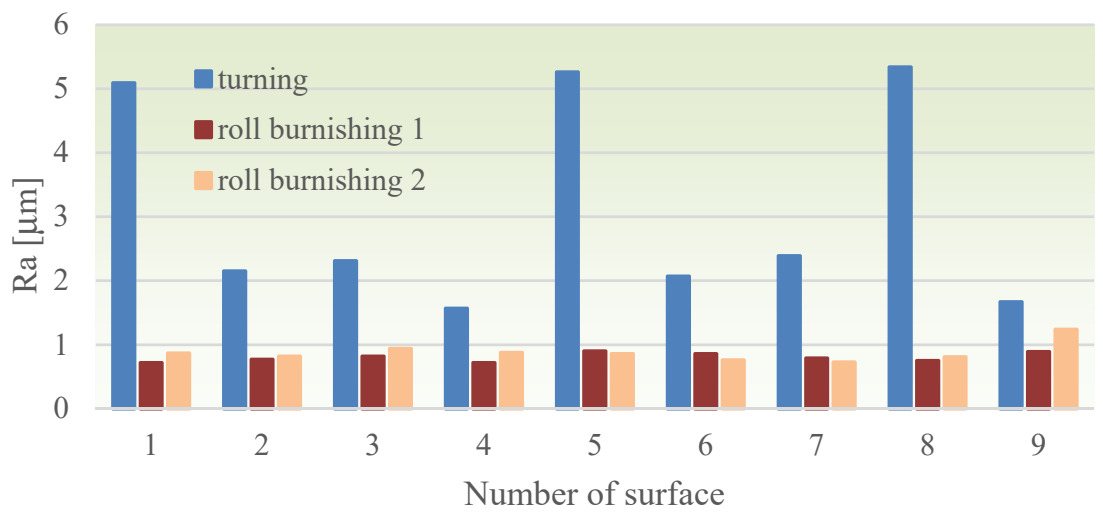

Fig. 5. Surface roughness - parameter Ra

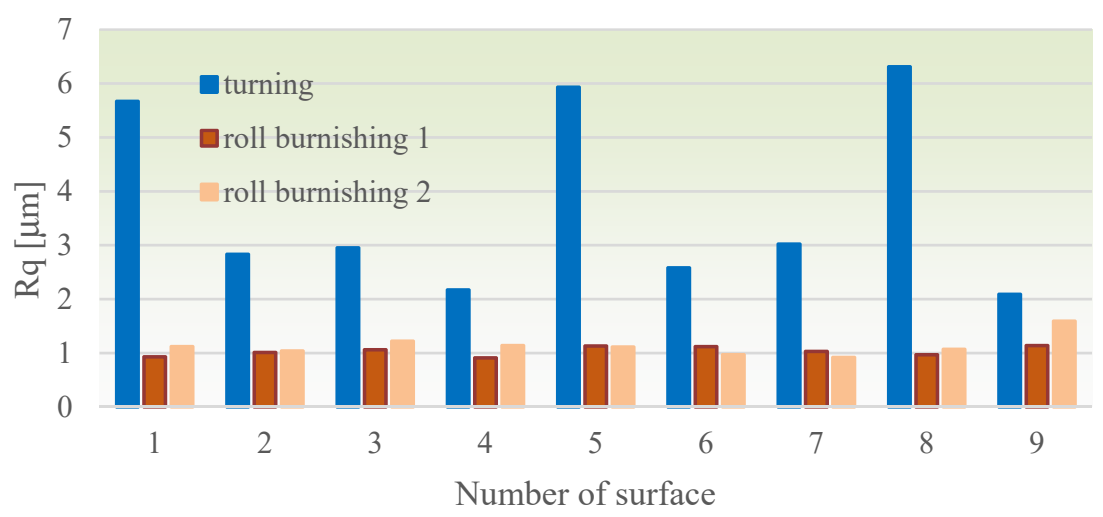

Fig. 6. Surface roughness - parameter Rq

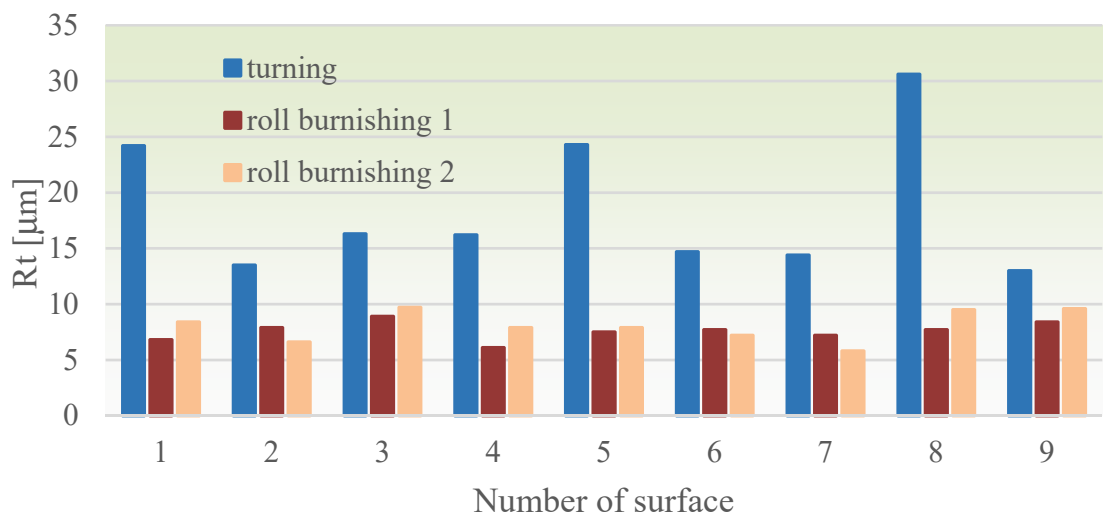

Fig. 7. Surface roughness - parameter Rt

Because the burnishing is essentially a cold forming process, in which the metal near a machined surface is displaced from protrusions to fill the depressions [21-23], there is the fig. 8 for to better illustrate changes of the surface profile. 
a)

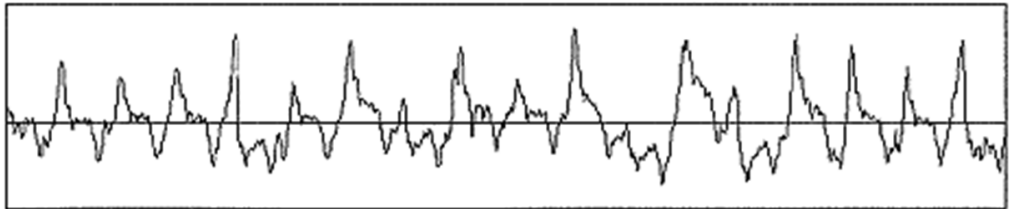

b)

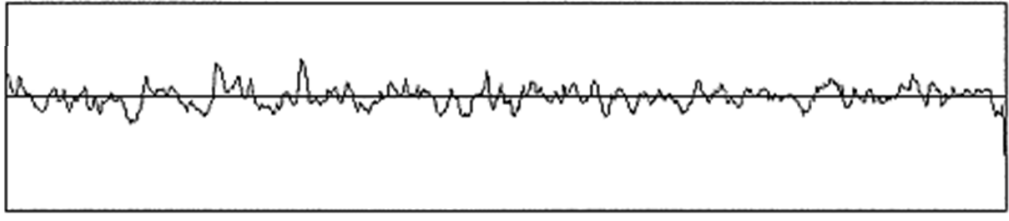

c)

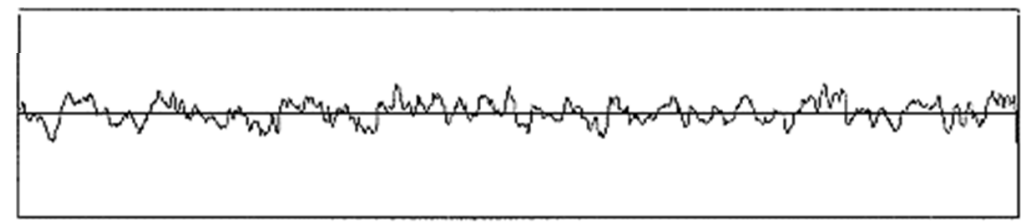

Fig. 8. Example of roughness profile (surface 3): a) after turning, b) after first roller burnishing, c) after second roller burnishing

On selected areas 8, 9 was measured roundness by the MK 300C device with rotating stylus. The MCC method (minimum circumscribed circle) was chosen as the evaluation method. In the MCC method, the profile center is determined by the smallest circle that contains the measured profile. From this center point, an inscribed circle fitted inside the profile is drawn. The out-of-roundness is the maximum inward departure from the circumscribed circle. Tab. 3 presents measured values of roundness on the surfaces 8 and 9 .

Table 3. Roundness of surfaces 8 and 9

\begin{tabular}{|c|c|c|c|}
\hline Number of & \multicolumn{3}{|c|}{ Roundness $[\mu \mathrm{m}]$} \\
\hline surface & Turning & First roller burnishing & Second roller burnishing \\
\hline $\mathbf{8}$ & 34,4 & 12,6 & 11,7 \\
\hline $\mathbf{9}$ & 10,8 & 11,6 & 16,9 \\
\hline
\end{tabular}

Figures 9 and 10 present a change of the roundness profile for better illustration because the roundness is only one numerical value.

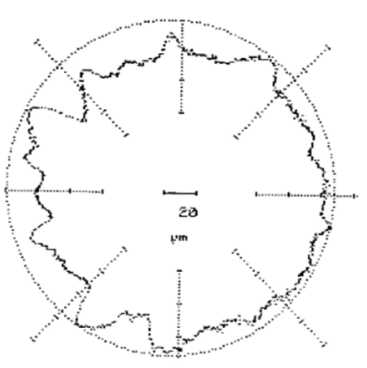

a)

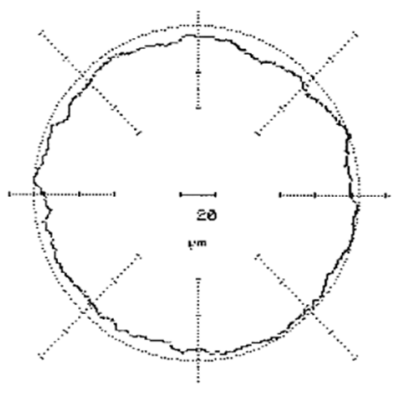

b)

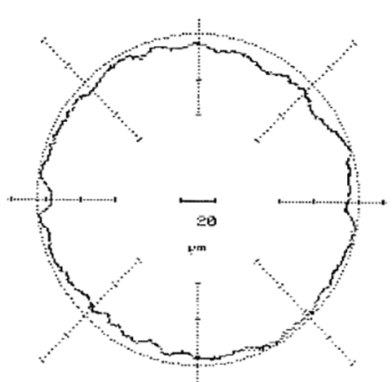

c)

Fig. 9. Roundness profile of surface 8: a) after turning, b) after first roller burnishing, c) after second roller burnishing 


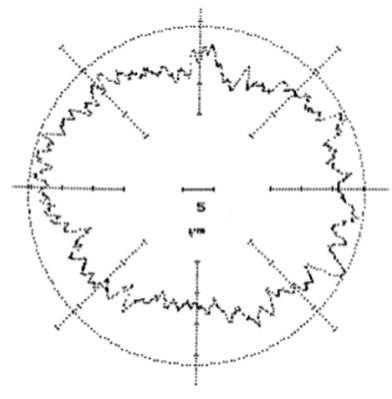

a)

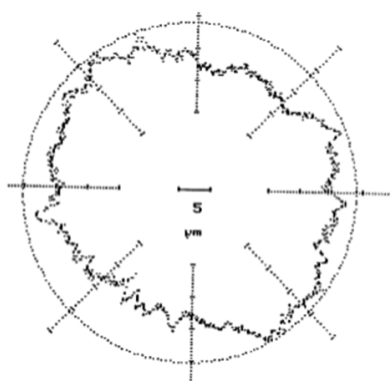

b)

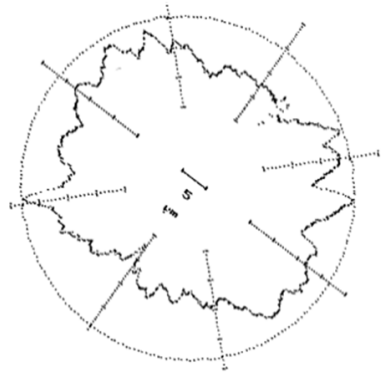

c)

Fig. 10. Roundness profile of surface 9: a) after turning, b) after first roller burnishing, c) after second roller burnishing

\section{Conclusion}

For commercial steel the experimental work showed:

- the original surface roughness had not significant influence on surface roughness after roller burnished - the rolled surface has approximately the same surface roughness on all surfaces regardless of the original surface roughness after turning,

- the surface roughness is decreasing after the first roller burnishing cycle (all monitoring parameters - Ra, Rq, Rt),

- if the original surface roughness is high, then the change of surface roughness after roller burnishing is significant. The turning surface with the highest surface roughness (surface No. 8) achieved an improvement of the Ra parameter of 86 percent, of the Rq parameter of 85 percent, of the Rt parameter of 85 percent,

- if the original surface roughness is low, then the change of surface roughness after roller burnishing is not so significant. The turning surface with the lowest surface roughness (surface No. 9) achieved an improvement of the Ra parameter of 47 percent, of the Rq parameter of 46 percent, of the Rt parameter of 35 percent,

- the above information confirm the manufacturer's tool recommendation, the surface roughness before roller burnishing should be $\mathrm{Ra}=3.2-6.3 \mu \mathrm{m}$,

- additional roller burnishing had only negligible influence on surface roughness - on some surfaces have improved, on some surfaces have worsened,

- if the original roundness is high, then it can be expected to improve after roller burnishing. If the roundness of the turned surface is low, cannot be expected to improve it, even it is possible the deterioration of the roundness.

The article was made under support grant project KEGA 022ŽU-4/2017 Implementation of on-line education in the area of precise technologies with an impact on educational process to increase skills and flexibility of students of engineering fields of study.

\section{References}

1. P. R. Babu, T. S. Prasad, A.V.S. Raju, A. Jawahar Babu, Effect of internal roller burnishing on surface roughness and surface hardness of mild steel, Journal of Scientific \& Industrial Research 68, 29-31 (2009)

2. S. Dolinšek, J. Kopač, Mechanisms and types of tool Wear; particularities in advanced cutting materials, Journal of Achievements in Materials and Manufacturing Engineering 19, 11-18 (2006) 
3. A. Stoić, I. Lacković, J.Kopač, I. Samardžić, D. Kozak, An investigation of machining efficiency of internal roller burnishing. Journal of Achievements in Materials and Manufacturing Engineering 40, 188-194 (2010)

4. B. B. Buldum, S. C. Cagan, The optimization of surface roughness of az91d magnesium alloy using ANOVA in ball burnishing process. Turkish Journal of Engineering 1, 25-31 (2017)

5. A. Kułakowska, L. Kukielka, K. Kukielka, R. Patyk, L. Malag, L. Bohdal, Possibility of Steering of Product Surface Layers Properties in Burnishing Rolling Process. Applied Mechanics and Materials 474, 442- 447 (2014)

6. L. Malag, L. Kukielka, K. Kukielka, A. Kułakowska, L. Bohdal, R. Patyk, Problems Determining of the Mechanical Properties of Metallic Materials from the Tensile Test in the Aspect of Numerical Calculations of the Technological Processes. Applied Mechanics and Materials 474, 454-459 (2014)

7. S. P. Dwivedi, S. Sharma, R. K. Mishra, Effects of roller burnishing process parameters on surface roughness of A356/5\% SiC composite using response surface methodology. Advances in Manufacturing 2, 303-317 (2014)

8. F. Gharbi, S. Sghaier, H. Hamdi, T. Benameur, Ductility improvement of aluminum $1050 \mathrm{~A}$ rolled sheet by a newly designed ball burnishing tool device. International Journal of Advanced Manufacturing Technology 60, 87-99 (2012)

9. R. J. Kosarevych, B. P. Rusyn and R. V. Torska, Modelling of the Propagation of Pitting Corrosion by Point Processes, Materials Science 51, 673-681 (2016)

10. B. P. Rusyn, N. P. Anufrieva, N. R. Hrabovska, V. H. Ivanyuk, Nondestructive Testing of the State of Surfaces Damaged by Corrosion Pitting. Materials Science 49, 516-524 (2014)

11. L. N. López de Lacalle, A. Lamikiz, J. A. Sánchez, J. L. Arana, The effect of ball burnishing on heat-treated steel and Inconel 718 milled surfaces. International Journal of Advanced Manufacturing Technology 32, 958-968 (2007)

12. M. H. El-Axir, An investigation into roller burnishing. International Journal of Machine Tools and Manufacture 40, 1603-1617 (2000)

13. H. Luo, J. Liu, L. Wang, Q. Wang, The effect of burnishing parameters on burnishing force and surface microhardness. International Journal of Advanced Manufacturing Technology 28, 707-713 (2006)

14. V. Franzen, M. Trompeter, A. Brosius, A. E. Tekkaya, Finishing of Thermally Sprayed Tool Coatings for Sheet Metal Forming Operations by Roller Burnishing. International Journal of Material Forming 3, 147-150 (2010)

15. Dodok, T., Čuboňová, N., Kuric, I. Workshop Programming as a Part of Technological Preparation of Production. Advances in science and technology. Research Journal, 11(1), 2017, 111-116

16. M. Sapieta, A. Sapietová, V. Dekýš, Comparison of the thermoelastic phenomenon expressions in stainless steels during cyckic loading. Metalurgija 56, Issue: 1-2, 203 206 (2017)

17. N. S. M. El-Tayeb, K. O. Low, P. V. Brevern, J. Influence of roller burnishing contact width and burnishing orientation on surface quality and tribological behaviour of Aluminium 6061. Journal of Materials Processing Technology 186, 272-278 (2007)

18. J. Petru, T. Zlamal, R. Čep, D Stančeková, M. Pagač, O. Vortel, Mechanism of cutting insert wear and their influence on cutting ability of the tool during machining of special alloys. METMG 2015 - 3rd international conference, Vancouver, Canada, 36-40 (2015) 
19. J. Novotný, J. Cais, N. Náprstková, Analysis of aluminium alloys AlSi7Mg0.3 and AlMg3 by means of X-Ray Diffraction. Manufacturing Technology, Vol. 14, No. 3, 392397 (2014)

20. M. Drbul, A. Czan, M. Sajgalik, M. Piesova, K. Stepien, Influence of normal vectors on the accuracy of product's geometrical specification. Conference: 12th International Scientific Conference of Young Scientists on Sustainable, Modern and Safe Transport Location: High Tatras. Procedia Engineering, Vol.192, 119-123 (2017)

21. R. J. N. Malleswara, K. R. A. Chenna, R. P. V. Rama, The effect of roller burnishing on surface hardness and surface roughness on mild steel specimens. International Journal of Applied Engineering Research 1, 777 (2011)

22. M. Kowalski, P. Karolczak A. Stadniczenko, Applicability of wavelet analysis in evaluation of roughness and waviness profiles of turned surfaces. Technological Engineering, Iss. 7, vol. 2, 66-69 (2010)

23. V. Poppeova, V. Bulej, R. Zahoransky, J. Uricek, Parallel mechanism and its application in design of machine tool with numerical control. Applied Mechanics and Materials, Vol. 282, 74-79 (2013) 